\title{
Composition of polyphenols of asparagus spears (Asparagus officinalis) and their antioxidant potential
}

\author{
Joanna Kobus-Cisowska ${ }^{1}$ (D) Daria Szymanowska ${ }^{1}$ (D) Oskar Marek Szczepaniak ${ }^{1^{*}}$ (iD

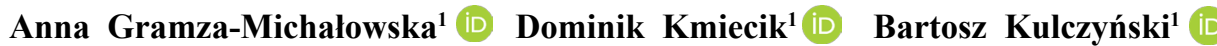 \\ Piotr Szulc ${ }^{2}$ (iD) Pawel Górnaś ${ }^{3}$ iD
}

${ }^{1}$ Faculty of Food Science and Nutrition, Poznan University of Life Sciences, Wojska Polskiego 31, 60-624, Poznan, Poland. E-mail: oskar.szczepaniak@up.poznan.pl..'Corresponding author.

${ }^{2}$ Faculty of Agronomy and Bioengineering, Poznan University of Life Sciences. Poznan, Poland.

${ }^{3}$ Institute of Horticulture, Latvia University of Life Sciences and Technologies. Jelgava, Latvia.

\begin{abstract}
The aim of this study was to examine the impact of cultivar and spear color on the composition of polyphenols in asparagus spears (Asparagus officinalis). The five genotypes (Schwetzinger Meisterschuss, Huchel's Alpha, Gijnlim, Grolim and Eposs) and three growing conditions of asparagus spears (Asparagus officinalis) were investigated. The polyphenols were determined by applying the HPLC-DAD system. The obtained results were subjected to the principal component analysis. Among the analyzed asparagus samples cv. Grolim contained the highest amounts of phenolic acids and flavonols. The varied quantitative and qualitative composition of polyphenolics resulted most probably from changes occurring during vegetation, such as a lack of access to light in the case of white asparagus and limited access to light in purple asparagus. The scavenging activity on DPPH radicals by asparagus extract is dependent on the variety and color and was the greatest for green asparagus samples. Similar green extracts scavenged ABTS radicals to the highest degree. Results of this study suggested that asparagus may constitute a good source of natural antioxidants to be used in our diet as well as by industries for functional food formulations.
\end{abstract}

Key words: asparagus cultivars, antioxidative activity, flavonols, phenolic acids, polyphenols.

A composição dos polifenóis das espargos (Asparagus officinalis) e o seu potencial antioxidante

RESUMO: O objetivo deste estudo foi examinar o impacto da cor da cultivar e da cor dos turiões na composição de polifenóis em aspargos (Asparagus officinalis). Os cinco genótipos (Schwetzinger Meisterschuss, Huchel's Alpha, Gijnlim, Grolim e Eposs) e três condições de cultivo de aspargos (Asparagus officinalis) foram investigados. Os polifenóis foram determinados aplicando o sistema HPLC-DAD. Os resultados obtidos foram submetidos à análise de componentes principais. Entre as amostras de aspargos analisadas a cv. Grolim continha as maiores quantidades de ácidos fenólicos e flavonóis. A composição quantitativa e qualitativa variada dos polifenóis resultou muito provavelmente de mudanças ocorridas durante a vegetação, como a falta de acesso à luz no caso dos aspargos brancos e o acesso limitado à luz nos aspargos purpúreos. A atividade sequestradora dos radicais DPPH pelo extrato de aspargos é dependente da variedade e cor, sendo que foi a maior para as amostras de aspargos verdes. Extratos verdes semelhantes capturaram os radicais ABTS no mais alto grau. Os resultados deste estudo sugerem que os espargos podem constituir uma boa fonte de antioxidantes naturais a serem utilizados em nossa dieta, bem como pelas indústrias para formulações de alimentos funcionais.

Palavras-chave: cultivares de espargos, atividade antioxidante, flavonóis, ácidos fenólicos, polifenóis.

\section{INTRODUCTION}

Asparagus officinalis L. is a perennial vegetable, which in the past was classified under the family Liliacea, while at present it comes under the Asparagaceae family. A characteristic feature of this group of plants is the fact that its root system does not wither in autumn, at the end of the vegetation season, but during winter. Because of the presence of many minerals, vitamins and bioactive compounds, asparagus has a beneficial effect on human health (PALFI et al., 2017; DROST, 2018). The edible parts of asparagus also contain certain amounts of phytosterols, which reduce blood cholesterol level. Among sterols the highest level is reported for $\beta$-phytosterol(over 50\%)(FUENTES-ALVENTOSA et al., 2009). Asparagus is primarily a rich source of flavonoids, including rutin and quercetin (PARK, 2016). Results from studies showed that the highest amounts of phenolic compounds are reported in purple 
and green asparagus. White asparagus is considered as a vegetable with a lower antioxidant potential. This means that exposure to light are required for the accumulation of phenolic compounds and that these compounds are accumulated particularly in asparagus tips (PAPOULIAS, et al., 2009; DAWID \& HOFMANN, 2014). The other research hypothesis concerns the polyphenols themselves, i.e. differences in total polyphenolic contents, particularly in the contents of phenolic acids and flavonols within analyzed cultivars and the three edible forms of each cultivar. Also, a thorough analysis was conducted of the polyphenolic compound content, i.e. phenolic acid derivatives of cinnamic and benzoic acids and flavonols, as well as assessment of the antioxidant potential measured by DPPH, ABTS and reducing power of five different asparagus cultivars (Grolim, Schwetzinger Meisterschuss, Gijnlim, Eposs, Huchel's Alpha) depending on their color: white, purple and green, resulting from the cultivation method adopted.

\section{MATERIALS AND METHODS}

The material used in the study comprised white, purple and green asparagus of the following cultivars: Schwetzinger Meisterschuss (DE 265), Huchel's Alpha, Gijnlim (NL 68), Grolim (NL 68) and Eposs (DE 265). Asparagus crops were harvested from four different plantations in Miedzichowo, the Nowy Tomyśl County, Poland (52²2’06.8” N 15'57'01.1” E). All fifteen samples of asparagus were cold stored for $24 \mathrm{~h}$ at a temperature of $3{ }^{\circ} \mathrm{C}$. Then, asparagus were cut into smaller pieces and boiled in water at a temperature of $95{ }^{\circ} \mathrm{C}$. Each asparagus sample was boiled in a separate uncovered pot for approximately $20 \mathrm{~min}$ until asparagus spears were soft. Upon completion of thermal treatment the tested material was homogenized. Next, the samples were lyophilized (CHRIST 1-4 LSC, Germany) - temperature on the freeze dryer shelf was heated and ranged from $+15{ }^{\circ} \mathrm{C}$ to $+20{ }^{\circ} \mathrm{C}$, temperature inside the product estimated $+4{ }^{\circ} \mathrm{C}$ and condensation temperature was set to $-48{ }^{\circ} \mathrm{C}$. The freeze drying was conducted at reduced pressure (1.030 mbar) by 48 hours.

Samples descriptions are given under table 1 .

Freeze dried asparagus samples (5 g) were homogenized and extracted in $70 \mathrm{ml}$ of $60 \%$ ethanol for $2 \mathrm{~h}$ at room temperature according to KOBUS-CISOWSKA and coworkers (2019) with slight modifications. The extract was filtered through Whatman No. 4 paper and rinsed with $50 \mathrm{ml}$ of ethanol.
Extraction of residue was repeated applying the same conditions. The two filtrates of $60 \%$ ethanol were combined and evaporated under vacuum at $40^{\circ} \mathrm{C}$; then freeze drying was conducted. The prepared crude extracts were stored in a dry, dark and cool place until they were analyzed.

Phenolic acids were analysed qualitatively and quantitatively using Agilent HPLC linked to a Bin Pump Infinity DAD 1290 detector $(\lambda=260 \mathrm{~nm}$ and $310 \mathrm{~nm}$ ). Phenolic acids were identified using the standards dissolved in methanol applying a method described by KOBUS et al. (2009).

The composition of flavonols was determined applying a method described by GRAMZA-MICHAŁOWSKA et al. (2016). Extracted flavonols were separated and identified by Agilent UPLC using a Nova-Pak C18 reversed-phase column $(3.9 \times 150 \mathrm{~mm}, 5-\mu \mathrm{m}$ particle size; both from Waters, Milford, MA, USA).

The antioxidative effect of asparagus was estimated using DPPH, ABTS and reducing power assays. The DPPH procedure described by AMAROWICZ et al. (2007) is based on the DPPH solution absorbance decrease at $\lambda=517$ $\mathrm{nm}$ in the presence of free radicals (Meterek SP 830, Taiwan). The DPPH r radical scavenging was presented as \% of scavenged radicals, EC50 and antiradical efficiency (AE) (AE=1/EC50). The ABTS radical cation decolourization assay was estimated according to RE and coworkers (1999), and was based on the spectrophotometric measurement $(\lambda=734 \mathrm{~nm})$. The results were expressed in the same way as \% scavenged DPPH, the EC50 value and antiradical efficiency (AE). The procedure of reducing power assay was described by AMAROWICZ and colleagues (2007). Absorbance of the produced mixture was measured at $700 \mathrm{~nm}$ with the use of a Specord 40 (Analytik Jena, Germany).

The data were analysed statistically by means of STATISTICA ${ }^{\text {TM }}$ PL 13.1 (StatSoft, Poland).

\section{RESULTS AND DISCUSSION}

In samples of tested white, purple and green asparagus cultivars selected phenolic acids and flavonols were determined qualitatively and quantitatively using HPLC (Table 1, Table 2).

Among the analysed hydroxycinnamic acids, gallic and $p$-hydroxybenzoic acids predominated, while among the derivatives of hydroxycinnamic acid it was ferulic, sinapic and coumaric acids. It was found that both the colour of 
Table 1 - HPLC analysis of phenolic acids in extracts of different cultivars and color of asparagus spears.

\begin{tabular}{|c|c|c|c|c|c|c|c|c|c|}
\hline Sample & Gallic Acid & $\begin{array}{l}\text { Protocatec } \\
\text { huic Acid }\end{array}$ & $\begin{array}{c}p- \\
\text { Hydroxybe } \\
\text { nzoic Acid }\end{array}$ & $\begin{array}{c}\text { Vanilic } \\
\text { Acid }\end{array}$ & $\begin{array}{c}\text { Caffeic } \\
\text { Acid }\end{array}$ & $\begin{array}{l}\text { Chlorogeni } \\
\text { c Acid }\end{array}$ & $\begin{array}{c}p- \\
\text { Coumaric } \\
\text { Acid }\end{array}$ & $\begin{array}{c}\text { Ferulic } \\
\text { Acid }\end{array}$ & $\begin{array}{l}\text { Sinapic } \\
\text { Acid }\end{array}$ \\
\hline GRw & $341.79^{f} \pm 13.11$ & nd & $\begin{array}{c}64.32^{g} \pm \\
5.52\end{array}$ & nd & nd & nd & $\begin{array}{c}73.27^{\mathrm{d}} \pm \\
4.83\end{array}$ & $\begin{array}{c}87.21^{\mathrm{d}} \pm \\
3.11\end{array}$ & $\begin{array}{c}51.72^{\mathrm{f}} \pm \\
3.04\end{array}$ \\
\hline $\mathrm{SCw}$ & $215.75^{\mathrm{e}} \pm 16.9$ & nd & $\begin{array}{c}28.94^{\mathrm{d}} \pm \\
2.28\end{array}$ & nd & nd & nd & $\begin{array}{c}40.75^{\mathrm{a}} \pm \\
1.23\end{array}$ & $\begin{array}{c}58.88^{\mathrm{a}} \pm \\
2.61\end{array}$ & $\begin{array}{c}34.55^{\mathrm{c}} \pm \\
2.39\end{array}$ \\
\hline GYw & $55.09^{\mathrm{bc}} \pm 7.06$ & $\begin{array}{c}22.19 \pm \\
0.57\end{array}$ & $\begin{array}{c}38.36^{\mathrm{e}} \pm \\
4.04\end{array}$ & nd & nd & nd & nd & $\begin{array}{c}58.64^{\mathrm{a}} \pm \\
2.35\end{array}$ & $\begin{array}{c}16.32^{\mathrm{a}} \pm \\
1.32\end{array}$ \\
\hline $\mathrm{EPw}$ & $73.68^{c} \pm 6.67$ & nd & $\begin{array}{c}16.26^{\mathrm{b}} \pm \\
1.64\end{array}$ & nd & $\begin{array}{c}4.40^{\mathrm{a}} \pm \\
0.44\end{array}$ & nd & $\begin{array}{c}44.63^{\mathrm{b}} \pm \\
2.92\end{array}$ & $\begin{array}{c}76.26^{\mathrm{b}} \pm \\
3.44\end{array}$ & $\begin{array}{c}34.59^{c} \pm \\
2.90\end{array}$ \\
\hline HUw & $107.10^{d} \pm 7.65$ & $\begin{array}{c}1.82 \pm \\
0.17\end{array}$ & $\begin{array}{c}22.20^{\mathrm{c}} \pm \\
0.22\end{array}$ & nd & nd & nd & $\begin{array}{c}40.69^{\mathrm{a}} \pm \\
3.22\end{array}$ & $\begin{array}{c}56.13^{\mathrm{a}} \pm \\
1.07\end{array}$ & $\begin{array}{c}29.24^{\mathrm{b}} \pm \\
0.68\end{array}$ \\
\hline GRp & $243.27^{\mathrm{e}} \pm 23.23$ & nd & $\begin{array}{c}44.62^{\mathrm{f}} \pm \\
2.77\end{array}$ & nd & $\begin{array}{c}10.49^{\mathrm{b}} \pm \\
0.52\end{array}$ & nd & $\begin{array}{c}65.98^{d} \pm \\
2.61\end{array}$ & $\begin{array}{c}83.72^{\mathrm{d}} \pm \\
7.80\end{array}$ & $\begin{array}{c}43.50^{\mathrm{e}} \pm \\
2.28\end{array}$ \\
\hline $\mathrm{SCp}$ & $76.97^{c} \pm 3.29$ & nd & $\begin{array}{c}19.44^{\mathrm{bc}} \pm \\
2.76\end{array}$ & nd & $\begin{array}{c}14.89^{\mathrm{bc}} \pm \\
0.81\end{array}$ & nd & $\begin{array}{c}56.09^{\mathrm{c}} \pm \\
3.81\end{array}$ & $\begin{array}{c}70.05^{\mathrm{b}} \pm \\
2.41\end{array}$ & $\begin{array}{c}37.45^{\mathrm{cd}} \pm \\
1.44\end{array}$ \\
\hline GYp & $39.57^{\mathrm{a}} \pm 2.46$ & $\begin{array}{c}2.10 \pm \\
0.69\end{array}$ & $\begin{array}{c}28.91^{\mathrm{d}} \pm \\
1.21\end{array}$ & nd & nd & nd & $\begin{array}{c}47.76^{\mathrm{b}} \pm \\
3.09\end{array}$ & $\begin{array}{c}59.93^{\mathrm{a}} \pm \\
1.39\end{array}$ & $\begin{array}{c}30.66^{\mathrm{c}} \pm \\
1.36\end{array}$ \\
\hline $\mathrm{EPp}$ & $124.75^{\mathrm{d}} \pm 11.46$ & nd & nd & nd & $\begin{array}{l}27.24^{\mathrm{cd}} \\
\pm 2.91\end{array}$ & nd & $\begin{array}{c}46.02^{\mathrm{b}} \pm \\
3.89\end{array}$ & $\begin{array}{c}77.06^{\mathrm{c}} \pm \\
4.17\end{array}$ & $\begin{array}{c}38.59^{\mathrm{cd}} \pm \\
2.18\end{array}$ \\
\hline HUp & $114.35^{\mathrm{d}} \pm 10.22$ & $\begin{array}{c}1.55 \pm \\
21.5\end{array}$ & $\begin{array}{c}23.09^{c} \pm \\
1.81\end{array}$ & nd & $\begin{array}{c}19.72^{b} \pm \\
0.13\end{array}$ & nd & $\begin{array}{c}56.46^{\mathrm{c}} \pm \\
1.52\end{array}$ & $\begin{array}{c}74.02^{\mathrm{c}} \pm \\
1.43\end{array}$ & $\begin{array}{c}17.06^{\mathrm{a}} \pm \\
0.86\end{array}$ \\
\hline GRg & $30.06^{\mathrm{a}} \pm 3.63$ & nd & $\begin{array}{c}59.57^{\mathrm{g}} \pm \\
2.31\end{array}$ & $\begin{array}{c}130.88^{\mathrm{c}} \pm \\
10.87\end{array}$ & $\begin{array}{c}31.50^{\mathrm{e}} \pm \\
1.37\end{array}$ & nd & $\begin{array}{c}178.17^{\mathrm{g}} \pm \\
10.61\end{array}$ & $\begin{array}{c}153.41^{\mathrm{f}} \pm \\
8.93\end{array}$ & $\begin{array}{c}85.81^{\mathrm{g}} \pm \\
5.81\end{array}$ \\
\hline $\mathrm{SCg}$ & $48.42^{b} \pm 3.59$ & nd & $\begin{array}{c}25.73^{\mathrm{c}} \pm \\
1.95\end{array}$ & $\begin{array}{c}102.54^{\mathrm{a}} \pm \\
9.54\end{array}$ & $\begin{array}{l}32.50^{\mathrm{e}} \\
\pm 2.36\end{array}$ & nd & $\begin{array}{c}139.00^{\mathrm{f}} \pm \\
21.65\end{array}$ & $\begin{array}{c}105.79^{\mathrm{e}} \pm \\
5.83\end{array}$ & $\begin{array}{c}46.89^{\mathrm{f}} \pm \\
1.29\end{array}$ \\
\hline Gyg & $33.02^{\mathrm{a}} \pm 1.22$ & nd & $\begin{array}{c}15.10^{\mathrm{b}} \pm \\
1.73\end{array}$ & $\begin{array}{c}120.28^{\mathrm{b}} \\
\pm 9.81\end{array}$ & $\begin{array}{l}22.12^{\mathrm{d}} \\
\pm 1.14\end{array}$ & nd & $\begin{array}{c}45.50^{\mathrm{b}} \pm \\
1.36\end{array}$ & $\begin{array}{c}57.28^{\mathrm{a}} \pm \\
4.93\end{array}$ & $\begin{array}{c}34.22^{\mathrm{c}} \pm \\
2.99\end{array}$ \\
\hline $\mathrm{EPg}$ & $196.77^{\mathrm{e}} \pm 10.72$ & nd & $\begin{array}{c}2.91^{\mathrm{a}} \pm \\
0.06\end{array}$ & $\begin{array}{l}179.72^{\mathrm{e}} \\
\pm 12.65\end{array}$ & $\begin{array}{c}18.98^{\mathrm{c}} \pm \\
0.59\end{array}$ & nd & $\begin{array}{c}91.80^{\mathrm{e}} \pm \\
9.42\end{array}$ & $\begin{array}{c}85.23^{\mathrm{d}} \pm \\
2.64\end{array}$ & $\begin{array}{c}39.14^{\mathrm{d}} \pm \\
1.39\end{array}$ \\
\hline HUg & $96.57^{d} \pm 3.75$ & nd & $\begin{array}{c}26.00^{\mathrm{cd}} \pm \\
1.88\end{array}$ & $\begin{array}{c}165.94^{\mathrm{d}} \pm \\
11.18\end{array}$ & $\begin{array}{c}6.98^{\mathrm{a}} \pm \\
0.09\end{array}$ & nd & $\begin{array}{c}75.82^{\mathrm{d}} \pm \\
3.68\end{array}$ & $\begin{array}{c}89.60^{\mathrm{d}} \pm \\
7.12\end{array}$ & $\begin{array}{c}33.05^{\mathrm{c}} \pm \\
0.55\end{array}$ \\
\hline
\end{tabular}

nd - not detected

Abbreviations are defined in Materials and methods - asparagus samples. Results are mean values of three determinations \pm standard deviation. Values sharing the same letter in a column are not significantly different $(\mathrm{P} \leq 0.05)$.

GRw - white asparagus Grolim, GRp — purple Grolim, GRg — green Grolim, SCw — white asparagus Schwetzinger Meisterschuss, SCp - purple Schwetzinger Meisterschuss, SCg — green Schwetzinger Meisterschuss, GYw — white asparagus Gijnlim, GYp — purple Gijnlim, GYg — green Gijnlim, EPw — white asparagus Eposs, EPp — purple Eposs, EPg — green Eposs, HUw — white asparagus Huchel's Alpha, HUp — purple Huchel's Alpha, Hug — green Huchel's Alpha.

asparagus and the cultivar had a significant effect on phenolic acid contents.

Presence of vanillic acid was identified solely in green asparagus. In turn, caffeic acid was identified only in one cultivar of white asparagus and in all cultivars of purple and green asparagus. As mentioned above, in white asparagus gallic acid was dominant for four tested asparagus cultivars. Eposs in the case of white asparagus contained less gallic acid than purple and green asparagus.
In the case of hydroxycinnamic acid derivatives, ferulic and sinapic acids were dominant acids in asparagus. Contents of these acids were generally highest in green asparagus and they were comparable in purple and white asparagus. Considerable amounts of p-coumaric acid were also detected, while it was lacking only in white Gijnlim. Chlorogenic acid was not detected. Protocatechuic acid was found only in four asparagus samples (GYw, HUw, GYp, HUp). 
Table 2 - HPLC analysis of flavonols in extracts of different cultivars and colour of asparagus spears [ $\mu \mathrm{g} / 100 \mathrm{~g} \mathrm{~d} . \mathrm{m}$.].

\begin{tabular}{|c|c|c|c|c|c|c|}
\hline & Rutin & Isoquercetin & Hyperoside & Astragalin & Quercetin & Kaempferol \\
\hline GRw & $31.85^{\mathrm{a}} \pm 1.39$ & nd & nd & nd & nd & nd \\
\hline $\mathrm{SCw}$ & $60.27^{\mathrm{a}} \pm 0.72$ & nd & nd & nd & nd & nd \\
\hline GYw & $217.77^{b} \pm 2.43$ & $9.23^{\mathrm{a}} \pm 9.22$ & $10.88^{\mathrm{a}} \pm 10.87$ & nd & nd & nd \\
\hline $\mathrm{EPw}$ & $222.08^{b} \pm 124.31$ & $11.26^{\mathrm{a}} \pm 11.26$ & $15.05^{\mathrm{a}} \pm 15.04$ & nd & nd & nd \\
\hline HUw & $230.24^{b} \pm 0.15$ & $28.68^{b} \pm 7.27$ & $13.02^{\mathrm{a}} \pm 13.02$ & nd & nd & nd \\
\hline GRp & $501.50^{\mathrm{b}, \mathrm{c}} \pm 15.67$ & nd & nd & nd & nd & nd \\
\hline $\mathrm{SCp}$ & $1543.69^{d} \pm 9.29$ & $24.08^{\mathrm{b}} \pm 0.34$ & nd & nd & nd & nd \\
\hline GYp & $790.54^{c} \pm 0.99$ & $13.59^{\mathrm{a}} \pm 0.16$ & $17.82^{\mathrm{a}} \pm 0.22$ & $21.89^{\mathrm{a}} \pm 21.89$ & nd & nd \\
\hline $\mathrm{EPp}$ & $1500.90^{d} \pm 6.11$ & $23.90^{\mathrm{b}} \pm 0.72$ & $42.19^{b} \pm 0.076$ & nd & $28.01^{\mathrm{a}} \pm 28.01$ & nd \\
\hline HUp & $1973.13^{d} \pm 93.75$ & $30.36^{b} \pm 0.15$ & $15.49^{\mathrm{a}} \pm 15.50$ & nd & nd & nd \\
\hline GRg & $16318.67^{\mathrm{e}} \pm 43.43$ & $97.08^{c} \pm 6.44$ & $182.10^{\mathrm{c}} \pm 12.90$ & $24.70^{\mathrm{a}} \pm 24.69$ & $52.10^{\mathrm{b}} \pm 52.10$ & nd \\
\hline $\mathrm{SCg}$ & $11942.87^{\mathrm{f}} \pm 819.0$ & $70.47^{c} \pm 0.39$ & $173.63^{c} \pm 0.09$ & $53.94^{\mathrm{b}} \pm 0.61$ & $43.59^{\mathrm{b}} \pm 9.77$ & nd \\
\hline Gyg & $1818.70^{\mathrm{d}} \pm 86.51$ & $28.16^{\mathrm{b}} \pm 1.07$ & $40.41^{\mathrm{b}} \pm 2.62$ & $18.21^{\mathrm{a}} \pm 0.12$ & $22.74^{\mathrm{a}} \pm 1.18$ & nd \\
\hline $\mathrm{EPg}$ & $14061.88^{\mathrm{e}} \pm 299.41$ & $50.07^{\mathrm{c}} \pm 10.34$ & $197.73^{\mathrm{c}} \pm 4.71$ & $55.58^{\mathrm{b}} \pm 10.11$ & $57.96^{\mathrm{b}} \pm 0.39$ & nd \\
\hline HUg & $10139.63^{\mathrm{g}} \pm 598.82$ & $55.95^{\mathrm{c}} \pm 0.25$ & $162.65^{\mathrm{c}} \pm 0.40$ & $43.75^{b} \pm 1.43$ & $55.80^{\mathrm{b}} \pm 0.25$ & nd \\
\hline
\end{tabular}

nd - not detected. $\mathrm{N}=3$. Abbreviations are defined in Materials and methods - asparagus samples. Results are mean values of three determinations \pm standard deviation. Values sharing the same letter in a column are not significantly different $(\mathrm{P} \leq 0.05)$.

It was found that among the analysed asparagus cultivars, Grolim contains the highest amount of phenolic acids with the smallest amounts detected in cv. Gijnlim. Green asparagus was found to have the highest content of phenolic acids, followed by purple and white asparagus.

Among all the cultivars, the highest amounts of flavonoids were found in green asparagus, among which cv. Grolim had the highest content of flavonols, with the lowest content in cv. Gijnlim. Rutin predominated in asparagus, as its content was detected at $1818 \mu \mathrm{g} / 100 \mathrm{~g} \mathrm{~d}$.m. in a sample of cv. GYg and up to $2318 \mu \mathrm{g} / 100 \mathrm{~g} \mathrm{d.m}$. in GRg. Purple asparaguses contained 10 times more rutin (501-1973 $\mu \mathrm{g} / 100 \mathrm{~g} \mathrm{d.m}$.) than white asparagus (31-230 $\mu \mathrm{g} / 100 \mathrm{~g}$ d.m.). No traces of astragalin or quercetin were detected in white and purple asparagus, while kaempferol was not found in any of the samples.

Close location of rutin to astragalin plots and ferulic acid to sinapic acid, indicates on the positive correlation between these factors
(Figure 1). However, the opposite location of gallic acid to $p$-coumaric acid as well as the location of $p$-hydroxybenzoic acid in order to isoquercetin, show that the correlations describing them are negative. The grouping of plots describing samples of white, purple and green asparaguses, indicates on the diversification of specimens up to the concentrations of analysed compounds.

Similar results concerning contents of phenolic acids in asparagus spears were presented by other researchers in which a dominant amount of hydroxycinnamic acids ranging from 2.31 to 4.91 $\mathrm{mg} / \mathrm{g}$ was presented (FUENTES-ALVENTOSA et al., 2009; PAPOULIAS et al., 2009). Moreover, middle and basal portions of the spears are richer in these compounds than the upper portion, especially after a storage period (RODRÍGUEZ, et al., 2005a; 2005b). The relatively high contents of gallic and $p$-hydroxybenzoic acids detected in asparagus result from the common occurrence of these compounds in the free state in gymnosperms, such as asparagus. Similar 


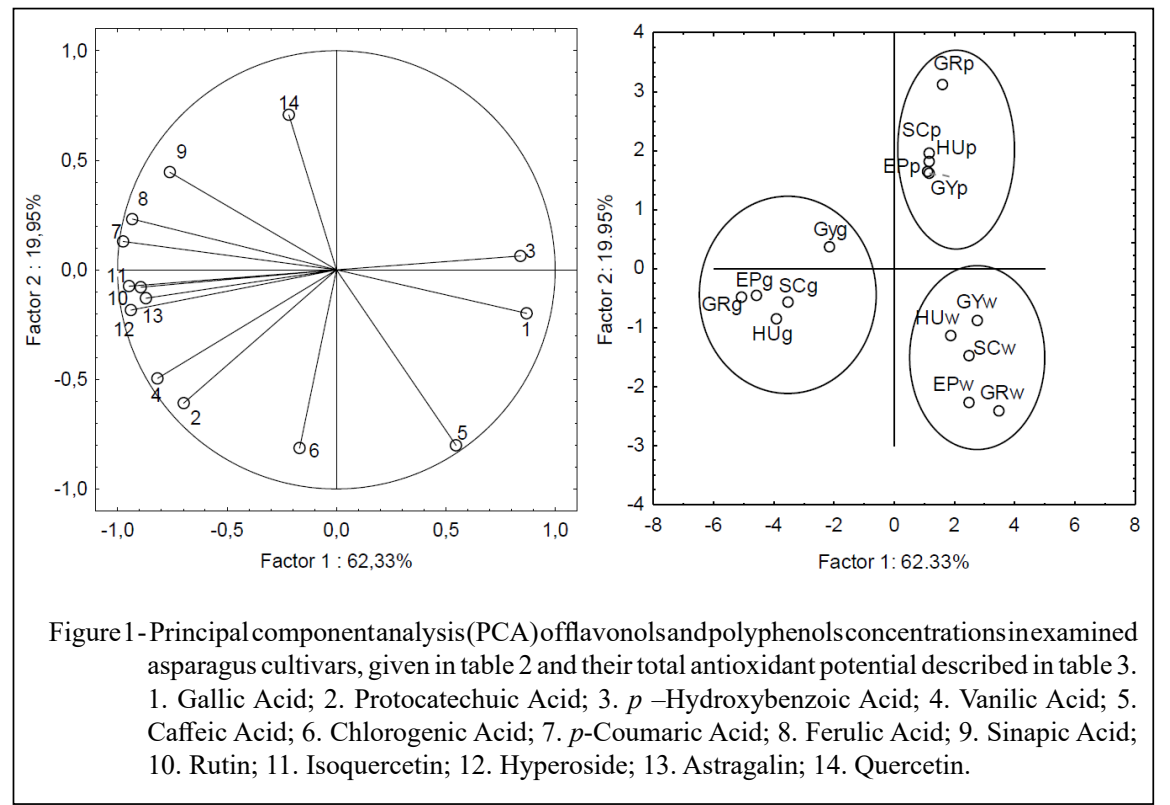

results were obtained for both green and purple asparagus by other authors, which indicates that green asparagus is more abundant in antioxidating phytochemicals (SHOU et al. 2007; KOHMURA et al. 2008). These compounds may influence the plant's antioxidant properties, which are based on the inhibition of free radical generation, their scavenging capacity and on increasing the catalytic activity of endogenous enzymes participating in the neutralization of free radicals (KMIECIK et al., 2015; YAO et al., 2016). This pertains in particular to p-hydroxybenzoic and gallic acids, as well as ferulic, sinapic and p-coumaric acids, which are predominant in asparagus.

The varied quantitative and qualitative composition in the case of polyphenolics resulted most probably from changes occurring during vegetation, such as a lack of access to light in the case of white asparagus and limited access to light in purple asparagus. Content of chemicals in plant organ depend on varieties (MUDAU et al. 2018). These proceedings are consistent with implications derived by FUENTES-ALVERTOSA and coworkers (2009). In their study, contents of flavonoids ranged from 25.9 to $76.3 \mathrm{mg} / 100 \mathrm{~g}$ fresh weight. Rutin (quercetin3-O-rhamnoglucoside) was the primary flavonoid glycoside, accounting for approximately $70 \%$ of total flavonoid content. According to SUN and coworkers (2007; 2007a), it was rutin that proved to be the most important flavonoid in asparagus. Its content was $286.5 \mathrm{mg} / \mathrm{kg}$ fresh product.

The antioxidative activity of asparagus was estimated using DPPH, ABTS and reducing power assays and is presented in table 3 and figure 2 .

Green asparagus had the highest antioxidant capacity measured with DPPH, followed by purple and white asparagus. It was found that green asparagus had EC50 within the range from 0.294 to 0.489 . The highest EC50 was shown for white asparaguses, which were 5 - to 8 -fold higher in relation to green asparaguses and by $15-42 \%$ higher in comparison to purple asparaguses. The scavenging activity on DPPH radicals by asparagus extract is variety- and colour-dependent.

The activity described as \% of scavenging radicals ranged from $16.07 \%$ for GYw to $95.90 \%$ for $\mathrm{SCg}$. The activity of green asparagus was the greatest for HUg. The value of IC50 for white asparagus was the highest and ranged from 1.11 for sample $\mathrm{HUw}$ to 1.92 for sample GYw. Green extracts scavenged ABTS radicals to the highest degree, amounting from 0.28 up to 0.48 .

High absorbance indicates high reducing power. It was shown that all the analysed extracts exhibited reducing power (Figure 2). However, the best performance, was observed in green asparagus samples with the lowest level in white asparagus spear extract. It has been shown that green Grolim asparagus 
Table 3 - Antioxidant activity of asparagus spears extract measured by DPPH and ABTS method and calculated by EC 50 [mmol/ml]; AE and $\%$ scavenging.

\begin{tabular}{|c|c|c|c|c|c|c|c|c|c|c|c|c|c|c|}
\hline \multicolumn{8}{|c|}{ 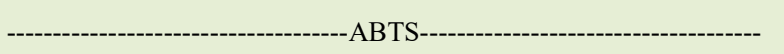 } & \multicolumn{7}{|c|}{ 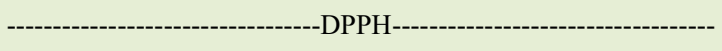 } \\
\hline \multirow{2}{*}{$\begin{array}{l}\text { Sample } \\
\text { GRw }\end{array}$} & \multicolumn{3}{|c|}{ EC $50[\mathrm{mmol} / \mathrm{ml}]$} & \multirow{2}{*}{$\begin{array}{c}\mathrm{AE} \\
1.33^{\mathrm{a}}\end{array}$} & \multicolumn{3}{|c|}{------\% scavenging---- } & \multicolumn{3}{|c|}{$\mathrm{EC} 50[\mathrm{mmol} / \mathrm{ml}]$} & \multirow{2}{*}{$\begin{array}{c}\mathrm{AE} \\
1.22^{\mathrm{a}}\end{array}$} & \multicolumn{3}{|c|}{---------\% scavenging------- } \\
\hline & $1.49^{\mathrm{f}}$ & \pm & 0.01 & & $16.21^{\mathrm{a}}$ & \pm & 2.43 & $0.75^{\mathrm{e}}$ & \pm & 0.03 & & $21.79^{\mathrm{a}}$ & \pm & 3.22 \\
\hline $\mathrm{SCw}$ & $1.63^{\mathrm{g}}$ & \pm & 0.02 & $1.23^{\mathrm{a}}$ & $14.38^{\mathrm{a}}$ & \pm & 2.44 & $0.81^{\mathrm{e}}$ & \pm & 0.02 & $1.16^{\mathrm{a}}$ & $19.33^{\mathrm{a}}$ & \pm & 3.23 \\
\hline GYw & $1.92^{\mathrm{h}}$ & \pm & 0.04 & $1.04^{\mathrm{a}}$ & $11.95^{\mathrm{a}}$ & \pm & 2.15 & $0.96^{\mathrm{e}}$ & \pm & 0.04 & $1.09^{\mathrm{a}}$ & $16.07^{\mathrm{a}}$ & \pm & 2.85 \\
\hline $\mathrm{EPw}$ & $1.26^{\mathrm{f}}$ & \pm & 0.05 & $1.58^{\mathrm{ab}}$ & $19.19^{\mathrm{ab}}$ & \pm & 2.11 & $0.63^{\mathrm{d}}$ & \pm & 0.01 & $1.75^{\mathrm{ab}}$ & $31.60^{b}$ & \pm & 2.79 \\
\hline HUw & $1.11^{\mathrm{e}}$ & \pm & 0.02 & $1.80^{\mathrm{b}}$ & $22.28^{b}$ & \pm & 3.34 & $0.55^{\mathrm{d}}$ & \pm & 0.03 & $1.88^{\mathrm{b}}$ & $36.68^{b}$ & \pm & 3.34 \\
\hline GRp & $1.19^{\mathrm{e}}$ & \pm & 0.06 & $1.87^{\mathrm{b}}$ & $22.13^{b}$ & \pm & 3.32 & $0.53^{\mathrm{d}}$ & \pm & 0.01 & $1.81^{\mathrm{b}}$ & $36.46^{\mathrm{b}}$ & \pm & 3.76 \\
\hline SCp & $0.95^{\mathrm{d}}$ & \pm & 0.03 & $2.35^{\mathrm{c}}$ & $27.60^{\mathrm{bc}}$ & \pm & 2.76 & $0.42^{\mathrm{bc}}$ & \pm & 0.02 & $2.015^{\mathrm{b}}$ & $45.47^{c}$ & \pm & 3.13 \\
\hline GYp & $0.95^{\mathrm{d}}$ & \pm & 0.02 & $2.16^{\mathrm{b}}$ & $26.14^{\mathrm{bc}}$ & \pm & 3.92 & $0.46^{\mathrm{c}}$ & \pm & 0.01 & $2.04^{\mathrm{b}}$ & $43.04^{c}$ & \pm & 4.45 \\
\hline $\mathrm{EPp}$ & $0.73^{\mathrm{c}}$ & \pm & 0.05 & $2.82^{\mathrm{c}}$ & $34.49^{c}$ & \pm & 3.10 & $0.35^{\mathrm{b}}$ & \pm & 0.01 & $2.55^{\mathrm{bc}}$ & $56.79^{d}$ & \pm & 3.52 \\
\hline HUp & $0.98^{\mathrm{d}}$ & \pm & 0.02 & $2.26^{\mathrm{b}}$ & $71.25^{\mathrm{d}}$ & \pm & 4.69 & $0.44^{\mathrm{c}}$ & \pm & 0.02 & $2.32^{\mathrm{b}}$ & $86.30^{\mathrm{e}}$ & \pm & 5.32 \\
\hline GRg & $0.29^{\mathrm{a}}$ & \pm & 0.04 & $8.29^{\mathrm{e}}$ & $91.18^{\mathrm{e}}$ & \pm & 7.88 & $0.12^{\mathrm{a}}$ & \pm & 0.01 & $7.33^{d}$ & $92.21^{\mathrm{f}}$ & \pm & 8.93 \\
\hline $\mathrm{SCg}$ & $0.28^{\mathrm{a}}$ & \pm & 0.02 & $6.64^{\mathrm{d}}$ & $79.17^{\mathrm{d}}$ & \pm & 6.33 & $0.15^{\mathrm{a}}$ & \pm & 0.05 & $5.27^{\mathrm{c}}$ & $95.90^{\mathrm{f}}$ & \pm & 6.29 \\
\hline GYg & $0.48^{\mathrm{b}}$ & \pm & 0.05 & $5.68^{\mathrm{d}}$ & $68.38^{\mathrm{d}}$ & \pm & 4.26 & $0.17^{\mathrm{a}}$ & \pm & 0.01 & $4.31^{\mathrm{c}}$ & $82.83^{\mathrm{e}}$ & \pm & 4.78 \\
\hline EPg & $0.28^{\mathrm{a}}$ & \pm & 0.05 & $7.19^{\mathrm{e}}$ & $86.91^{\mathrm{e}}$ & \pm & 4.56 & $0.13^{\mathrm{a}}$ & \pm & 0.01 & $7.55^{\mathrm{d}}$ & $87.89^{\text {ef }}$ & \pm & 4.53 \\
\hline HUg & $0.36^{\mathrm{ab}}$ & \pm & 0.03 & $5.52^{\mathrm{d}}$ & $66.42^{\mathrm{d}}$ & \pm & 2.31 & $0.18^{\mathrm{a}}$ & \pm & 0.02 & $5.94^{\mathrm{c}}$ & $80.45^{\mathrm{e}}$ & \pm & 2.29 \\
\hline
\end{tabular}

Results are means \pm S.D. $(n=3), P<0.05$; values of the same column, followed by the same letter are not statistically different $(\mathrm{P}<0.05)$.

had reducing power close to BHT - the synthetic antioxidant. It may be observed that asparagus GR and SC exhibited higher activity than other asparagus varieties in all colour groups. Statistical analysis showed that there is a positive correlation between the content of flavonols and the reducing power of asparagus extracts $(\mathrm{r}=0.754)$ and between phenolic acids and reducing power $(\mathrm{r}=0.783)$.

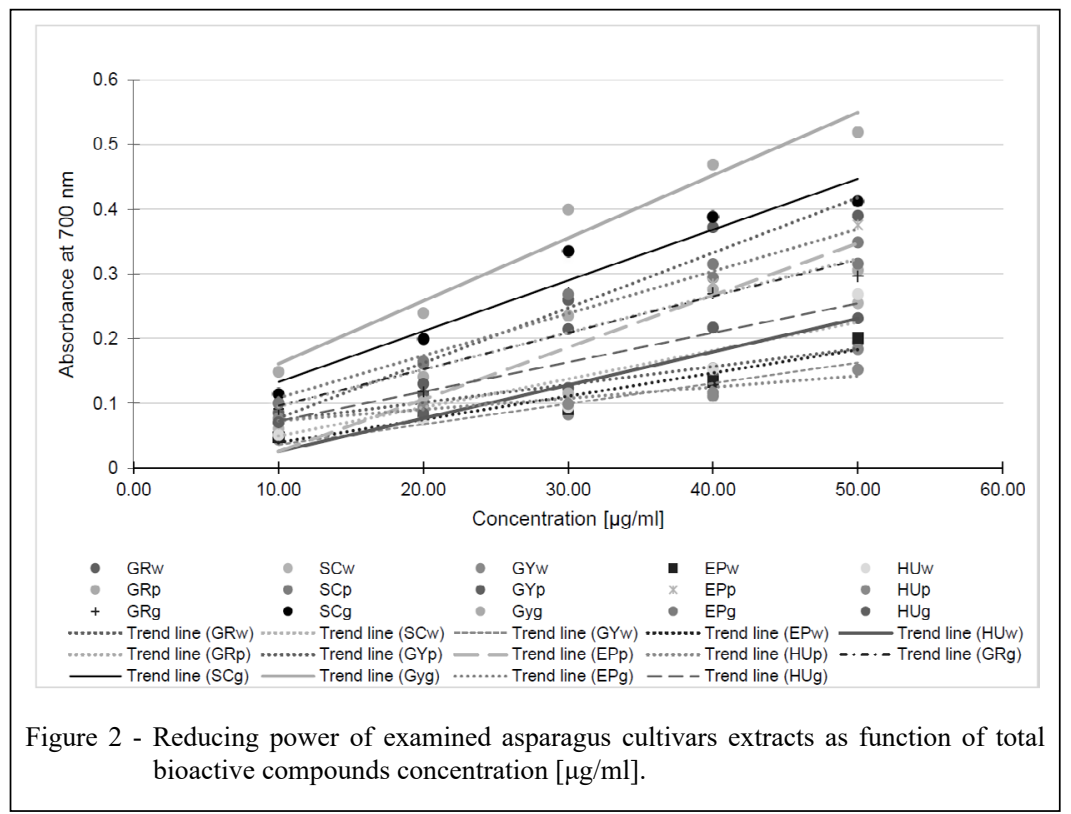

Ciência Rural, v.49, n.4, 2019. 
The free radical scavenging activities of green asparagus were attributed to various natural polyphenols, including rutin, quercetin, kaempferol, and isorhamnetin (FUENTES-ALVENTOSA et al., 2009). Our result was in agreement with two previous reports that the antioxidant activity of asparagus was correlated with polyphenol contents. In previous study it was indicated that asparagus with the highest radical scavenging activity in relation to DPPH, i.e. green asparagus (KULCZYŃSKI et al., 2016). The analyses also made it possible to identify cv. Gijnlim and Grolim as cultivars exhibiting the highest scavenging potential in relation to the DPPH radicals.

In turn, a study by KOBUS-CISOWSKA and coworkers (2017) showed that bioactive components of green asparaguses and their high antioxidant potential enhance nutritive value of meat products. Addition of green asparagus to meatloaf had a statistically significant effect on an increase in antioxidant activity measured in the DPPH test, with $0.30 \mathrm{mmol} \mathrm{TE} / \mathrm{g}$ product in the control, while in meatloaves with asparaguses (added at 1.5, 2 and $3 \%$ ) it was $0.49,0.57$ and $0.73 \mathrm{mmol} \mathrm{TE} / \mathrm{g}$ product. Similarly, in the ABTS test the activity in relation to the control was by as much as 3.5 times greater.

\section{CONCLUSION}

Spears of asparagus have been consumed as vegetable for centuries, but very little information is available on the bioactive compounds and their antioxidant activity, which depend on cultivars and color. In the present study, five cultivars (Grolim, Schwetzinger Meisterschuss, Gijnlim, Eposs, Huchel's Alpha), each in white, green and purple color, were compared in terms of their polyphenol contents. Contents of phenolic compounds in asparagus varied and depended both on the cultivar and color of the vegetable. Asparagus was found to contain phenolic acids and flavonoids, among which gallic acid, ferulic acid and rutin predominated. The highest amounts of bioactive compounds were detected in green asparagus, with the contents being lower in purple asparagus, while white asparaguses were the poorest sources of these compounds. Among the tested asparagus cultivars cv. Grolim had the highest contents of phenolic acids and flavonols. The scavenging activity towards DPPH radicals by asparagus extract is variety- and color-dependent and was the greatest for green asparagus samples. Similar green extracts scavenged ABTS radicals to the highest degree. Statistical analysis showed a significant positive correlation between flavonols and phenolic acids and the activity towards DPPH and ABTS radicals. The presence of such fenolic acids as gallic, ferulic and sinapic acids, contributed to the highest antioxidant activity towards DPPH radicals. The antioxidant activity measured with ABTS of asparagus demonstrated a linear relationship with rutin content. The capability of the asparagus spears to scavenge DPPH and ABTS radicals and act as reducers, indicate that they may be useful therapeutic agents in treating radical pathological damage.

The information shown in this paper could be of interest with regards to both expanding scientific knowledge and possible further practical applications.

\section{ACKNOWLEDGEMENTS}

The work was financed by grant POIR.04.01.0200-0059/17 from the National Centre for Research and Development in Poland.

\section{DECLARATION OF CONFLICTING OF INTERESTS}

The authors declare no conflict of interest. The founding sponsors had no role in the design of the study; in the collection, analyses, or interpretation of data; in the writing of the manuscript, and in the decision to publish the results.

\section{AUTHORS' CONTRIBUTIONS}

Joanna Kobus-Cisowska conceived and designed experiments. Others authors contributed equally to the manuscript. All authors critically revised the manuscript and approved of the final version.

\section{REFERENCES}

AMAROWIC, R., et al. Antioxidant and radical scavenging activities of a barley crude extract and its fraction. Czech J. Food Sci. v. 25, n. 2, p. 73-80, 2007, Available from: $<$ https://www. agriculturejournals.cz/publicFiles/00090.pdf>. Accessed: Mar. 15, 2019. doi: 10.17221/755-CJFS.

DAWID, C., HOFMANN, T., Quantitation and bitter taste contribution of saponins in fresh and cooked white asparagus (Asparagus officinalis L.). Food Chem. v. 145, p.427-436, 2014. Available from: $<$ https://www.sciencedirect.com/science/article/ pii/S0308814613011382> Accessed: Mar. 15, 2019. doi: 10.1016/j. foodchem.2013.08.057.

DROST, D. A Single application of phosphorus at planting improves long-term asparagus root growth and yield. Int. J. Veg. Sci. v. 24 , n. 2, p. 146-159. 2018. Available from: <https://www. tandfonline.com/doi/abs/10.1080/19315260.2017.1398197> Accessed: Mar 15, 2019. doi: 10.1080/19315260.2017.1398197.

FUENTES-ALVENTOSA, J.M. . et al. Effect of the extraction method on phytochemical composition and antioxidant activity of high dietary fibre powders obtained from asparagus by-products. Food Chem. v. 116, n. 2, p. 484-490, 2009.Available from: $<$ https:// www.sciencedirect.com/science/article/pii/S0308814609002799>. Accessed: Mar. 15, 2019. doi: 10.1016/j.foodchem.2009.02.074. 
GRAMZA-MICHAŁOWSKA, A., et al. Antioxidative potential, nutritional value and sensory profiles of confectionery fortified with green and yellow tea leaves (Camellia sinensis). Food Chem. v. 211, p. 448-454, 2016. Available from: $<$ https://www. sciencedirect.com/science/article/pii/S0308814616307294>. Accessed: Mar. 15, 2019. doi: 10.1016/j.foodchem.2016.05.048.

KMIECIK, D., et al. Stabilisation of phytosterols by natural and synthetic antioxidants in high temperature conditions. Food Chem. v. 173, p. 966-971, 2015. Available from: <https://www. sciencedirect.com/science/article/pii/S0308814614016367>. Accessed: Mar. 15, 2019. doi: 10.1016/j.foodchem.2014.10.074.

KOBUS-CISOWSKA, J., et al. Applicability of asparagus (Asparagus officinalis L.) as a component of meatloaf. Nauk. Przyr. Technol. v. 11, p. 87-96, 2017. Available from: <http:// www.npt.up-poznan.net/tom11/zeszyt1/art_8.pdf $>$. Accessed: Mar. 15, 2019. doi: 10.17306/J.NPT.00174.

KOBUS-CISOWSKA J., et al. In vitro screening for acetylcholinesterase and butyrylcholinesterase inhibition and antimicrobial activity of chia seeds (Salvia hispanica). Elect. J. Biotechn. v. 37, p. 1-10, 2019. Available from: <https://www. sciencedirect.com/science/article/pii/S0717345818300411> Accessed: Mar. 15, 2019. doi: 10.1016/j.ejbt.2018.10.002.

KOBUS, J., et al. Phenolic compounds and antioxidant activity of extracts of Ginkgo leaves. Eur. J. Lipid Sci. Technol. v. 111, p. 1150-1160, 2009. Available from: <https://onlinelibrary.wiley. com/doi/abs/10.1002/ejlt.200800299>. Accessed: Mar. 15, 2019. doi: 10.1002/ejlt.200800299.

KOHMURA, H., et al. Polyphenol content, antioxidant activity and surface colour of asparagus spears cultivated under different conditions of sunlight. Acta Hortic. v. 776, p. 255-260, 2008. Available from: $<$ http://www.actahort.org/books/776/776_32.htm> Accessed: Mar. 15, 2019. doi: 10.17660/ActaHortic.2008.776.32.

KULCZYŃSKI, B., et al. Antiradical capacity and polyphenol composition of asparagus spears varieties cultivated under different sunlight conditions. Acta Sci. Pol. Technol. Aliment. v. 15, n. 3, p. 267-279, 2016. Available from: <https:/www.food.actapol.net/ volume15/issue/4_3_2016.pdf>. Accessed: Mar. 15, 2019. doi: 10.17306/J.AFS.2016.3.26

MUDAU, A.R., et al. The quality of baby spinach as affected by developmental stage as well as postharvest storage conditions. Acta Agric. Scand. Sect. B - Soil Plant Sci. p. 1-10, n. 1, 2018. Available from: <https://www.tandfonline.com/doi/abs/10.1080/0 9064710.2018.1492009? journalCode $=$ sagb20 $>$. Accessed: mar 15, 2019. doi: 10.1080/09064710.2018.1492009.

PALFI, M., et al. Total polyphenol content and antioxidant activity of wild and cultivated asparagus in Croatia. Poljoprivreda. v. 23, n. 1, p. 56-62, 2017. Available from: <http://poljoprivreda.pfos. $\mathrm{hr} / \mathrm{upload} /$ publications/poljoprivreda-23-1-9.pdf $>$. Accessed: Mar. 15, 2019. doi: 10.18047/poljo.23.1.9.
PAPOULIAS, E., et al. Effects of genetic, pre- and post-harvest factors on phenolic content and antioxidant capacity of white asparagus spears. Int. J. Mol. Sci. v. 10, n. 12, p. 5370-5380, 2009. Available from: <https://www.ncbi.nlm.nih.gov/pmc/ articles/PMC2801999/>. Accessed: Mar. 15, 2019. doi: 10.3390/ ijms10125370.

PARK, M.-H. Sucrose delays senescence and preserves functional compounds in Asparagus officinalis L. Biochem. Biophys. Res. Commun. v. 480, n. 2, p. 241-247, 2016. Available from: <https:// www.sciencedirect.com/science/article/pii/S0006291X16317119>. Accessed: Mar. 15, 2019. doi: 10.1016/j.bbrc.2016.10.036.

RE, R., et al. Antioxidant activity applying an improved ABTS radical cation decolorization assay. Free Radic. Biol. Med. v. 26, n. 9-10, p. 1231-1237, 1999. Available from: <https://www. sciencedirect.com/science/article/pii/S0891584998003153>. Accessed: Mar. 15, 2019. doi: 10.1016/S0891-5849(98)00315-3.

RODRÍGUEZ, R., et al. Cell wall phenolics of white and green asparagus. J. Sci. Food Agric. v. 85, n. 6, p. 971-978. 2005a. Available from: $<$ https://onlinelibrary.wiley.com/doi/full/10.1002/ jsfa.2053>. Accessed: Mar. 15, 2019. doi: 10.1002/jsfa.2053.

RODRÍGUEZ, R., et al A. Antioxidant activity of ethanolic extracts from several asparagus cultivars. J. Agric. Food Chem. v. 53, n. 13 , p. $5212-5217,2005$ b. Available from: $<$ https://pubs. acs.org/doi/10.1021/jf050338i>. Accessed: Mar. 15, 2019. doi: $10.1021 /$ jf050338i.

SHOU, S., LU, G., HUANG, X. Seasonal variations in nutritional components of green asparagus using the mother fern cultivation. Sci. Hortic. v. 112, n. 3, p. 251-257, 2007. Availablefrom: $<$ https://www.sciencedirect.com/science/article/pii/ S0304423806005280>. Accessed: Mar. 15, 2019. doi: 10.1016/j. scienta.2006.12.048

SUN, T., et al. Evaluation of the antioxidant activity of asparagus, broccoli and their juices. Food Chem. v. 105, n. 1, p. 101-106, 2007. Available from: <https://www.sciencedirect.com/science/ article/pii/S0308814607002956>. Accesed: Mar. 15, 2019. doi: 10.1016/j.foodchem.2007.03.048.

SUN, T., et al. Antioxidant activity and quality of asparagus affected by microwave-circulated water combination and conventional sterilization. Food Chem. v. 100, n. 2, p. 813-819, 2007a. Available from: <https://www.sciencedirect.com/science/ article/pii/S0308814605009519>. Accessed: Mar. 15, 2019. doi: 10.1016/j.foodchem.2005.10.047.

YAO, X.-H., et al .Different harvest seasons modify bioactive compounds and antioxidant activities of Pyrola incarnata. Ind. Crops Prod. v. 94, p. 405-412, 2016. Available from: <https:// www.sciencedirect.com/science/article/pii/S0926669016305465>. Accessed: Mar. 15, 2019. doi: 10.1016/j.indcrop.2016.08.03. 